\title{
A Call for New Thinking: Geopolitics, Security, Economics ${ }^{1}$
}

\author{
The Honorable Stuart E. Eizenstat ${ }^{2}$
}

$\mathrm{E}$ urope Day is celebrated to recognize the creation by Robert Schuman, a great French diplomat, of his concept after World War II of a new European construct. It is hard to imagine that the ideas of visionaries like Schuman, Jean Monnet, Paul Henri Spaak and Walter Hallstein of what started as a small European coal and steel community with six countries, initially in the European Economic Community after the Treaty of Rome in 1957, would blossom into a union with 28 member states and 500 million people. What has happened with the European Union is absolutely unique. There is no other institution in world history in which sovereign member states have come together, not in a "UN"-type organization, not in a G-7 or G-20, but in which they have pooled whole areas of their sovereignty and given it to a central institution while still maintaining other areas of sovereignty. And after the EU started, it reformed itself with the 1992 Maastricht Treaty, the 1997 Amsterdam Treaty, the 2001 Nice Treaty, and the creation in the Lisbon Treaty of 2009 of the Common Foreign and Security Policy.

\section{EU Accomplishments}

What are the accomplishments on Europe Day that we can look at and admire and be inspired by? The first is that the European Union is literally the first institution that created a peaceful Europe since the period between 1870 and 1945, during which time there were three major wars involving substantial parts of the European Continent. Since the creation of the European Union and its predecessors, there have been no wars between its member states, now 28. And indeed, not only have there been no wars, but almost all the members of the European Union are also members of NATO. Under Article 5 of NATO these countries have pledged each other to common defense, of which the United States is a part if anyone is attacked. So far, from being a threat to each other, they now are bound together by a defense pact. But interestingly, it's not just NATO. The European Union has its own mutual defense pact in which the EU members, again 28, have pledged to come to each other's common defense and to use all means necessary if any of them are attacked.

The second great achievement for the European Union on Europe Day is that it is the first time in which Western and Eastern Europe have been united under democratic free market principles. The only times there was even the semblance of unity is when there was a Napoleon or some military leader who forcefully brought countries together. Here, free countries have come together from the east and the west. What is remarkable is that after the collapse of communism, the Fall of the Berlin Wall, and the end of the Cold War, within the short period of two decades, all the major Eastern Bloc countries, all the countries that were under the thumb of the Soviet Union, all the countries that for decades lived without democracy, without free speech, without tolerance, without human rights under communist dictatorship, came together in the European Union.

The consequence of the incentive to join the EU with its free market, democratic tolerance and human rights principles was to, much more rapidly than would have otherwise been possible, embed themselves in those very principles. It is really remarkable that in two decades since 1990, here in the beginning of the second decade of the $21^{\text {st }}$ Century, there are now 28 member states, many of which lived under communism, now embodying the very principles which Monnet and Spaak and the other founding fathers created. The attraction of EU membership and the EU Association Agreements is substantial for countries that are not yet members and was one of the sparks for the Ukrainian problems. And when the promise and hope of memberships fades, as it has for Turkey unfortunately, since Turkey has the longest standing application to EU membership, then the democratic reforms that Turkey has made have themselves begun to evaporate. There are very troubling signs in Turkey now, in part because they've lost hope for membership.

The third thing to celebrate on this Europe Day is the creation of a remarkable set of enduring and durable institutions based in Brussels such as the European Union Commission. The Commission is the equivalent of our U.S. Executive Branch. It proposes legislation, it proposes ideas, and it conducts trade relations and negotiations. It has the power to bind the member states on key issues like trade. If anyone in the legal field or in the business field has any merger involving a European and an American company, it also has to go through the competition commissioner who has the sole jurisdiction to pass on mergers and acquisitions. This is a real functioning executive body.

A second institution which has developed significantly is the European Parliament. This is the elected body that represents the citizens, the people of Europe. And they voted in May's parliamentary elections, electing Members of the European Parliament (MEPs) for their countries who will represent them as citizens of Europe as well as of their country. The MEPs form political blocs like the socialist bloc, or People's Party bloc, just like the U.S. has the Democratic and Republican parties, but perhaps more functional. It is a real parliament with appropriation authority, with legislative authority.

And the third major institution is the European Council, which represents the 28 member states, has its own president, and roughly, is the equivalent of the U.S. Senate because it also has to approve legislation in order for a law to come into effect.

The next institution which is worth celebrating started only in 1986 with the Single European Act and the creation of

\footnotetext{
1 Address to the World Affairs Council of Atlanta on the Occasion of Europe Day 2014, 08. May, 2014.

2 Stuart E. Eizenstat is Partner, Covington \& Burling LLP and Former United States Ambassador to the European Union (1993-96).
} 
what we call the common market, eliminating all barriers to trade in products, services, finance and to the govement of people. People from Poland can work in the UK - the famous Polish plumber issue. And it's almost as easy for a product to go from Greece to Germany, or from France to Sweden, as it is from Georgia to South Carolina. There are virtually no barriers, with common regulatory schemes through mutual recognition - really a remarkable achievement.

In addition, another institution which is worth mentioning and being inspired by is the more recent 1995 creation of a monetary union, now with 18 of the 28 countries, a European Central Bank, like our Federal Reserve, and a currency, the Euro. There are now 334 million Europeans who use the Euro every day, and another 110 million people around the world, including, by the way, 82 million in Africa, who have pegged their currency not to the dollar, but to the Euro. The Euro is the second most circulated currency. It is the second reserve currency in the world next to the United States dollar. And, adding the coins and paper, it actually exceeds the U.S. dollar. As U.S. Ambassador to the EU from 1993 to 1996, when the European Union was just beginning to debate the creation of the Euro and monetary union, I sent cables back to Washington saying this may happen, which were then still met with great derision. How can you possibly bring economies as disparate as those in southern and northern Europe under one union? One anecdote may illustrate that this was a political decision, not just an economic decision. I went to see the French Ambassador to the EU, who was a cousin to de Gaulle (and he let you know he was), and I said "Mr. Ambassador, are you really prepared to give up the French franc with all of its years of history and Louis XIV on the note, for a Euro?" He responded, "Mr. Ambassador, you do not understand. Do you know that we have fought three wars with Germany? If there is a common currency in which we and Germany are locked together, countries can't go to war against their own currency. It will assure there will never be a war between Germany and France." The birth of the Euro was a dramatic political statement - a dramatic commitment to bind countries together that had been at each other's throats for so long.

\section{Three "Wake-up Calls"}

That is the good news. Now, let's consider some of the challenges that I would call "wake-up calls" that the EU has faced and is facing as we speak. The first wake-up call was the Euro crisis 2009-2010, which threatened the very foundation of the Euro, and seems to validate those doubters at the Treasury Department and State, who said you can't bring these disparate economies together. Now, I want to make it very clear, Europe didn't start the Euro crisis - it started right here in River City, in the United States. It was our profligacy, our bad mortgages rated AAA, our Lehman Brothers. But the impact of what we started, reverberated in a violent economic way in Europe, and shook the very foundations of the Euro and the monetary union; countries like Greece with 27 percent unemployment or Spain with 50 percent youth unemployment. The currencies and the banks were under great threat and the spreads between the bonds in Greece and those for example in Germany, were traumatic. So a 10-year bond at the height of the crisis carried a 30 percent interest rate. No country can afford that. The same thing happened in Spain and in Ireland. And it really shook the entire institution to its very core.

Could Europe come out of this? Well it has, because of a number of things. Haltingly, yes, but our response to our crisis was halting also, because the financial crisis we experienced in 2008 and 2009 was something no living person or adult for sure, had known since the Great Depression. So, first the EU created a 500 billion Euro European stability mechanism to try to create some kind of safety net under those countries most at risk. And only last year, June of 2013, they agreed that 60 billion Euros of that 500 billion could be used to help those banks in needy member states that were most at risk. Now remember, these are pooled resources. It's really quite remarkable. Yes, I wish Germany had acted faster but it is also the German public who is paying for this.

The second thing after the 60 billion was a very important, a historic statement by the real hero. And that hero is Mario Draghi, the President of the European Central Bank in Frankfurt. The markets were going manic. They were driving bonds up to 30 percent in Greece, 25 percent in Ireland - punishing rates that no country could afford to ever pay back. And Draghi said in very simple terms, "I will do everything that it takes" to make sure that there are no sovereign defaults. And it was like puncturing a bubble. He has never had to spend one Euro to back that statement up because his credibility and the European Central Bank's credibility is such that no one wanted to bet against it; and so now that 30 percent 10-year bond in Greece is 6 percent, and Greece has come back into the credit markets just within the last few weeks with a very well-received bond, and so has Spain, and so has Ireland. This incredible crisis is now, at one level, over. The Euro is secure, and it is hard to imagine there will ever be a repeat of this kind of crisis.

Having said that, it's important to recognize that there is another shoe on this foot. We took a very different approach in the United States to our great recession and to our financial crisis than Europe. We stimulated. The Fed purchased trillions of dollars of mortgage-backed securities and other bonds that it is only now beginning to unwind. We had a fiscal policy that was expansionary. Europe took exactly the opposite tack - austerity and belt tightening. It would be futile to talk about who was right and who was wrong. We took very different approaches, but everyone would now say that with the Euro saved, there have been real punishing implications for this austerity. Yesterday, in Greece there have been demonstrations arising from the tremendous amount of pain and suffering, and nationalist, even anti-Semitic, parties like the Golden Dawn, have arisen because of the people's frustration.

So it is critical now for the other shoe to drop. It is now time for a growth policy in Europe so that kids have a chance of getting a job. And it is especially important because the demographics in Europe are very different than they are in the United States. We're a much younger society and, although we have our own entitlement problems, they are more severe in Europe because their retirements are richer. They retire earlier, and they have 
fewer workers to support those retirees. So, the forecast is that in 2013 Europe grew at one tenth of one percent, just above zero. The estimates for 2014 are one and a half percent, but that is half of what it will be in the United States, where we expect 3 percent. And that is not enough to cut into this massive unemployment.

\section{So, here are some suggestions:}

- First, Europe needs thorough-going labor market reforms.

- Second, state assets need to be sold, and

- Third, it is critically important that the European Union and the U.S. complete the negotiations for a Transatlantic Trade and Investment Partnership (TTIP) agreement which has now been negotiated for a number of months.

TTIP is a deficit-free, inflation-free, stimulus for Europe and the United States. It will add a billion dollars of GDP to bothone full percent in Europe, a half of a percent here in the U.S. It will create hundreds of thousands of new jobs. It is the most ambitious, the most comprehensive trade agreement ever negotiated, far exceeding even those in the World Trade Organization with a 150 or 200 countries. It covers everything - tariffs on products, tariffs on agriculture goods, intellectual property, labor mobility, services, and we must make sure it is successful. We have so much riding on it.

I want to make another point about TTIP. As important as it is as a growth engine for Europe and for us, there is an even more important, broader geopolitical reason why we have to succeed. The agreement will bind the U.S. and Europe together indelibly. Both are now 50 percent of total world GDP. Both account for a third of all global trade, but with the reset and focus on Asia, it is important that Europe knows that the United States is not going to abandon the countries that share western values. When the U.S. has to negotiate with Iran on the nuclear issue, or on Syria, or deal with Russia, we don't go to Thailand or Japan or China. Yes, these are important new markets, but we go to Europe, because that is where we share common values and outlook. And so there is a geopolitical importance to this agreement. If we can deliver, it is a way of standing up to the Chinese and Russian state-controlled models of capitalism that were put out to the developing world as the new model for the $21^{\text {st }}$ Century. It is our model which is just as relevant in the $21^{\text {st }}$ Century as in the $20^{\text {th }}$ - free markets, free peoples, free and protected intellectual property, free thought, innovation, tolerance. We have got to be able to show that this model works in the $21^{\text {st }}$ Century, and this is one of the tests for it.

Now, there is a second wake-up call, the first being this Euro crisis, which Europe has met the first test for, but still needs to take the second on growth. And that second wake-up call occurred with the breakup of the post-Cold War Yugoslavia in 1991-92, and then the wars in Bosnia in 1992 to 1995. The Foreign Minister of Luxembourg, which held the rotating presidency of the Council of Europe, famously declared: "This is the hour of Europe, not the hour of America." He was dead wrong. Europe was unable to muster the capability of intervening and stopping this ethnic cleansing, and it took American-led military intervention in Bosnia and later in Kosovo, to end this inglorious part of European late $20^{\text {th }}$ century history. But out of tragedy came positive developments because the EU realized that it was unable to muster a common policy.

And so, the much debated and finally passed Lisbon Treaty went into effect at the end of 2009, just a few years ago. The European Union created a Common Foreign and Security Policy with a high representative, now Lady Catherine Ashton, who conducts foreign policy for the EU. There is still and will always be a foreign minister from France and from the UK and so forth. But the degree of coordination, while it is not perfect, as a result of the Lisbon Treaty is impressive. So it is the EU that is part of the so-called quartet on Middle East Policy. It is Lady Ashton who is negotiating with Secretary Kerry and Ambassador Wendy Sherman with Iran on nuclear power and the nuclear issue. This is a very, very meaningful thing. There are in fact now 3,000 new diplomats in a European External Service in 130 countries around the world - a real foreign service, like our career foreign service in the state department. We all travel, and when we have a problem, we go to the U.S. Embassy or a consulate. And now there are 130 of these delegations from the European Union. It is a remarkable thing.

And that gets to me to the third and last challenge - the third wake-up call. And it is one we have not woken up to. The alarm is still ringing, and we're sleeping. And that is what's happening in Ukraine and Russia. This is not something out of the blue, where Putin simply woke up on the wrong side of the bed one day. It is part and parcel of a well-conceived policy. It started with Transnistria in Moldova which is a Russian-speaking entity, and which declared its independence and was recognized by Russia - only Russia. Then in 2008, while we all slept, Russia invaded Georgia and carved out two Pro-Russian enclaves of Abkhazia and South Ossetia, with hundreds of Georgian soldiers killed and the internal displacement of over a hundred thousand people.

Look at what has happened in the Ukraine not in isolation. It is part of President Putin's well thought through policy of exerting influence on his so-called near abroad that he sometimes calls the "new Russia." Get a group of Russians in any one of these countries, and it is important for him to protect them, even if it means carving the country up. What has happened in the Ukraine is a watershed. It is a watershed for the U.S.; it is a watershed for the EU; it is a watershed for the west, because it means that the whole post-World War II and post-Cold War construct is being threatened. As President Obama eloquently stated, if a large country can simply violate the territorial integrity of a smaller one, where are we in the $21^{\text {st }}$ Century?

Now, the Ukrainians were not blameless in this situation. They gave Putin the opportunity to do what he wanted because when the European Union was just about finished with its negotiations for an EU Accession Agreement, Putin began to say wait a minute now, Ukraine is on our border. Ukraine was part of the Soviet Union. Now it's going to be leaning to, if not a future member of, the European Union. And that is when the pro-Russian President, under Putin's pressure, decided against signing the final report. There were riots in the streets against President Yanukovych and what then happened was that three EU foreign ministers, including the Polish foreign minister, negotiated on behalf of the EU what seemed to be 
a solution to the problem which the Russians would have acquiesced to: to keep Yanukovych in office until December, earlier than his term would normally end, and to have early elections. And when the demonstrations then threw him out, one of the first acts of the new Ukrainian interim governor in Kiev was to seemingly take away the Russian language rights of the Russian ethnic Ukrainians in the East, just exactly what Putin needed.

And so Putin took the Crimea, annexed it, and made it a part of Mother Russia. It was a pretty good day's work for him because the costs were very minimal. We put some of the usual suspects on a Visa ban and asset freeze, and he could say "you know, if this is all there is, how about the rest of Eastern Ukraine?" Now there is an effort to destabilize major cities like Donetsk and others in Eastern Ukraine by a group of pro-Russian thugs, so called green men, who don't have any markings on their Russian outfits. Somehow that is supposed to mask who they are. They have taken over government buildings and police stations, and the Ukrainian military is so disabled, so corrupted, that they are not able to take those places back. This also violates directly the 1994 Budapest Memorandum signed by Russia saying that Ukraine's territorial integrity will be maintained.

And yet with all of this, the EU sanctions are even less strong than those the U.S. imposed, which at least have targeted a few Russian banks and some of the major figures around Putin, including the bank in which Putin does his banking.

Why has the EU not taken firmer action? They have a Common Foreign and Security Policy; they have a High Representative who sits with secretaries of state. They were willing, to their great credit, to really join with the U.S. in applying tough sanctions on Iran. That is why Iran is at the bargaining table. They agreed with us to expel all private Iranian banks from the Brussels-based Swift system, which clears all dollar international transactions. They targeted the Central Bank of Iran and even more remarkable, much more self-sacrificial on their part, they decided that they would accept no Iranian oil imports. That was 18 percent of their total oil imports. They now get zero from Iran. Why? Because their trade relationship and commercial relationship with Russia is much larger. Ours is about 50 billion dollars a year which is six or seven times less than the amount for Europe, and because Germany gets a third of its natural gas from Russia, and other European countries like Slovakia likewise depend on it. So, they are tied in knots. What did we see just within the last week, at the height of this crisis? The CEO of Siemens goes to Moscow and meets with President Putin to assure him that nothing will interfere with their business relationships with Russia.

\section{Some Prescriptions}

I want to close by suggesting specific prescriptions, and I want to do so in this context. Russia does not hold all the economic cards. It is true that Europe heavily depends on Russian energy. It is also true that Russia has to have customers for that energy. Fifty percent of their total revenues for their government come from their energy sales. They have had, even before the full sanctions bit in the first quarter of this year, 50 billion dollars of capital flight, a 10 percent drop in their stock market, foreign direct investment basically stopped. If we can show the determination to apply meaningful sanctions, it can have a real impact. So, here are my suggestions:

- First and now, don't make the red line for meaningful sanctions the tanks coming in with those 40,000 troops that Russia has amassed on the border, because that won't happen. Why should it happen? Putin doesn't need it to happen. He is already destabilizing Eastern Europe without doing it. The red line should be if he causes such destabilization as to make the May $25^{\text {th }}$ elections in Ukraine impossible to freely carry out, because people particularly in the south and east of Ukraine are intimidated from voting. That is what he wants to do so there is no legitimate government elected on May 25. We have to be very clear now that that type of action will occasion the same kind of tough sanctions on their financial institutions, on their mining industry, and on their energy industry, as would a direct invasion. There was a good start on this just a few days ago when Chancellor Merkel, to her credit, and President Obama in Washington, pledged that if these elections were destabilized by Russia, it would occasion much stronger and firmer sanctions. It is critical that this not just be rhetoric, not like the red line in Syria. We have got one chance to show Western will, and if we blow it, we will pay a horrible price, into our children and grandchildren's time.

- Second, the EU should announce now that it is going to start on a long-term and medium-term European Energy Policy that will reduce its dependence on Russian natural gas because of the geopolitical risks involved. Even stating that will have an important impact. And that Energy Policy should involve the following:

- The development of pipelines connecting the 28 countries of the EU, which do not go through Russia. The U.S. must support the southern route pipeline that will take gas and oil out of the Caspian Sea to the EU, without traveling through Russia.

- The beginning of development of plentiful shale gas and oil resources in Europe, including France, Germany and Poland, which they will not start at all because of environmental objections.

Now, if this Ukrainian situation had occurred five years from now, certainly ten years from now, it would be a very different situation because we will be within three years, perhaps within 18 months - we, the United States of America, of being the number one natural gas producer in the world. In less than ten years, because of this fracking technology, the U.S. will be the number one crude oil producer, more than Saudi Arabia and more than Russia. There is a terminal being built right now in Louisiana, and when it's completed in 2017, this one terminal alone can supply one-sixth of the natural gas for Europe. And there are 25 terminals waiting for licenses. We have got to get the bureaucracy to make those licenses approved, because if we can build those terminals, it will make us a mammoth natural gas producer. There are only two ways to export natural gas - through a pipeline 
and through liquefying it. And to serve Europe, we have got to liquefy it. So, we have got to get it passed, and that's the American part.

- We have also got to encourage Germany to rethink its shutting off of its nuclear power. What that has done is make it more dependent on Russian gas and on dirty coal.

- And last, the West has got to get together and make Ukraine a success story by marshalling the billion dollars of Congress' appropriated money with that from the European Union, which it's willing to do, and from the IMF, so that we can make sure that it works.

Two final thoughts: The European members of NATO have consistently refused to honor their pledge to spend at least 2 percent of their GDP on defense. We are at 4 percent. The average in the EU is one and a half percent. If they make that decision, we must invigorate NATO and move forward with placement of troops on the front lines, like in Poland, and in the other Visegrad countries - Hungary, the Czech Republic and Slovakia. There is also no U.S. carrier in the Mediterranean. Those fleets need to be deployed. We have got to show a determination, and the best way to avoid a military confrontation is to do it through tough sanctions and through building up NATO.

I want to close with this thought on Europe Day. The EU has come so far. It is a truly remarkable success story. Now, to really undergird the dream of Jean Monnet and of Robert Schuman and the other founding fathers, it is time to meet this new $21^{\text {st }}$ Century national security threat by working together with the U.S. and demonstrating that the very idea upon which the EU was founded, the very construct, we will not permit any country on the European continent to wreck. That will be a real Europe Day.

\section{Mit Sicherheit unsicher - \\ Reader zur Konflikt- und Friedensforschung und zur Sicherheitspolitik}

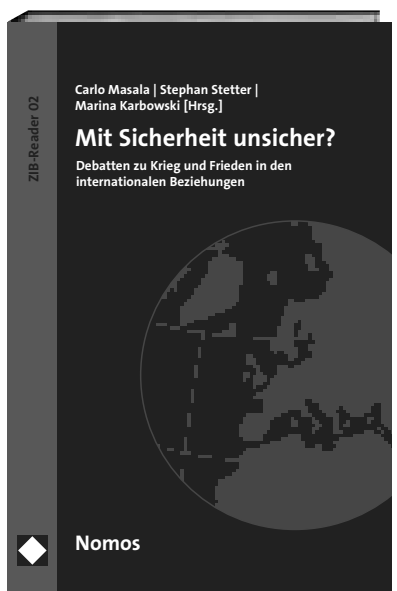

Der Reader beinhaltet Beiträge aus der Friedens- und Konfliktforschung sowie der Sicherheitsforschung, und er bietet einen umfassenden Überblick über Theorie und Empirie in diesen Forschungsbereichen.

In diesem Sammelband kann die Entwicklung und Genese theoretischer Ansätze nachvollzogen werden. Auch verdeutlicht der Reader, wie neue Forschungsgegenstände in diesen Forschungsfeldern erschlossen wurden.

\author{
Mit Sicherheit unsicher? \\ Debatten zu Krieg und Frieden in den \\ internationalen Beziehungen \\ ZIB-Reader \\ Herausgegeben von Carlo Masala, \\ Stephan Stetter und Marina Karbowski \\ 2014, 383 S., brosch., 49,- $€$ \\ ISBN 978-3-8487-0970-0 \\ www.nomos-shop.de/21844
}

Durch kommentierte Bibliographien werden die Beiträge in den Kontext aktueller Debatten gesetzt. Damit eignet sich der Reader zur Konzeption von Referaten und Kursen. Er kann sowohl in Einführungs- als auch weiterführenden Seminaren als Grundlage verwendet werden. 